\title{
IMPLEMENTASI PENDIDIKAN KARAKTER BERBASIS MULTIKULTURAL DI SMK NEGERI 2 MATARAM
}

Oleh:

Nurlaili Handayani, Taat Wulandari

Universitas Negeri Yogyakarta, Universitas Negeri Yogyakarta

Email: nurlailihandayani9@gmail.com, taat_wulandari@uny.ac.id

\begin{abstract}
Abstrak
Penelitian ini bertujuan untuk: mengetahui implementasi pendidikan karakter berbasis multikultural di SMKN 2 Mataram, dan untuk mengetahui faktor pendukung dan penghambat dalam implementasi pendidikan karakter berbasis multikultural di SMKN 2 Mataram. Penelitian ini merupakan penelitian kualitatif dengan pendekatan naturalistik. Pemilihan subjek penelitian dilakukan menggunakan teknik purposive sampling dan snowball sampling. Pengumpulan data melalui wawancara, observasi, dan dokumentasi. Keabsahan data menggunakan teknik tringulasi. Analisis data menggunakan reduksi data, penyajian data, dan penarikan kesimpulan. Hasil penelitian menunjukkan bahwa implementasi pendidikan karakter berbasis multikultural dilaksanakan melalui programprogram sebagai berikut: a) komitmen manajemen sekolah; b) melalui tata tertib sekolah; c) pengintegrasian pada program intrakurikuler; d) pengintegrasian pada program ekstrakurikuler; e) budaya sekolah dan f) program jaringan kerja. Sekolah mengembangkan nilai-nilai karakter: nilai religius, mandiri, peduli lingkungan, berprestasi, toleransi, demokratis, semangat kebangsaan, kompetitif dan cinta damai. Faktor pendukung antara lain: a) komitmen dan kerjasama yang baik antara kepala sekolah, guru, siswa, dan keterlibatan orang tua wali; b) dukungan pihak pemerintah dan swasta dalam jaringan kerja. Faktor penghambat antara lain: a) kebiasaan dan budaya lingkungan asal siswa yang berbeda; b) lingkungan masyarakat; c) lingkungan teman sebaya dan media elektronik; e) sarana prasarana yang belum lengkap; f) evaluasi program pendidikan karakter yang belum optimal, sehingga mempengaruhi proses penanaman karakter.
\end{abstract}

Kata Kunci: pendidikan karakter, multikultural, multikultural di SMK

\begin{abstract}
This study aimed to investigate: the implementation of multiculturalism-based character education, and the facilitating and inhibiting factors in the implementation of multiculturalism-based character education at SMK Negeri 2 Mataram. The study used the qualitative method with the naturalistic approach. They were selected by means of the purposive and snowball sampling techniques. The data were collected by, namely interviews, observations, and documentation. The data trustworthiness was enhanced by the triangulation technique. The data were analyzed by of data reduction, data display, and conclusion drawing. The results of the study are as follows. 1) The multiculturalism-based character education was implemented through the following programs: a) the school management commitment; b) the disciplined attitude building through regulations; c) the integration of intra-curricular programs; d) the integration of extracurricular programs; e) the school culture and f) network programs. School developed values such as religiosity, autonomy, care of the environment, achievement, tolerance, democracy, nationalism, competitiveness, and love of peace. 2) The facilitating factors included among others: a) good commitment and cooperation among the school principal, teachers, students, and parents' involvement in various aspects of school activities; and b) the government and private support within the network. The inhibiting factors included among others: a) the habits and cultural environments of students' origins which were varied; b) the social environment; c) the peer environment and electronic media; e) incomplete infrastructure facilities; and f) evaluation of program character education that had not been optimal, so that it affected the process of character inculcation.
\end{abstract}

Keywords: character education, multiculturalism, multiculturalism in SMK 


\section{Pendauluan}

Indonesia merupakan negara dengan masyarakat yang sangat majemuk, ditandai dengan berbagai macam suku, agama, etnis, budaya, bahasa daerah dan adat istiadat. Selain itu, Indonesia juga merupakan negara kepulauan, dengan jumlah pulau sekitar 17.504. Jumlah pulau yang mencapai puluha ribu tersebut berimbas pada banyaknya ragam suku, budaya, dan bahasa yang ada di Indonesia. Hasil survei yang dilakukan oleh Badan Pusat Statistik (BPS, 2015) menyatakan bahwa Indonesia dihuni oleh sekitar 1.128 suku, yang tersebar di seluruh nusantara dari Sabang sampai Merauke. Banyaknya suku yang tersebar tersebut sepadan dengan jumlah penduduk Indonesia yang mencapai 253.609.643 juta jiwa. Indonesia memiliki keunikan, dilihat dari konstruksi masyarakat yang beragam. Kemajemukan masyarakat Indonesia terlihat dari penyebaran agama yang berbeda antara lain; Islam $(87,18 \% \%)$, Kristen $(6,95 \%)$, Katolik $(2,91 \%)$, Hindu (1,69\%), Budha $(0,72 \%)$ dan Konghuchu $(0,05 \%)$, dan sisanya menganut kepercayaan lainnya. Multikultural bangsa Indonesia dapat dimengerti sebagai sesuatu yang terjadi secara alami. Keadaan Indonesia yang multikultural menuntut setiap orang untuk mampu membuka diri dalam menjalani kehidupan bersama, dengan melihat realitas plural yang telah melekat pada jati diri bangsa Indonesia sejak lama.

Permasalahan yang terjadi dewasa ini telah banyak melibatkan generasi muda Indonesia, seperti masalah tawuran antar pelajar, kerap terjadinya aksi bulliying di dunia pendidikan, bahkan kekerasan lainnya yang melibatkan para pelajar. Keseluruhan permasalahan yang terjadi di Indonesia diindikasi muncul karena adanya prasangka antara kelompok, masih dijumpai rendahnya kesadaran masyarakat untuk saling mengerti akan perbedaan, masih terlihatnya sikap individual dan kelompok dalam tatanan masyarakat, masih ada ditemui kelompokkelompok yang merasa superior dari yang lainnya Hal ini tidak terlepas dari belum optimalnya penanaman sikap menghargai perbedaan pada proses pendidikan di Indonesia, yang diindikasikan belum sepenuhnya menekankan betapa pentingnya menghargai perbedaan sebagai suatu bangsa yang berdaulat dengan semboyan Bhinneka Tunggal Ika.

Sleeter (2014, p.99), mengungkapkan bahwa pemahaman terhadap konsep multikultural adalah kebijakan pada praktik pendidikan dalam mengakui, menerima dan menegaskan perbedaan dan persamaan manusia yang dikaitkan dengan gender, ras, kelas sosial, dan agama. Pendidikan adalah cermin dari wajah suatu bangsa. Dalam proses pendidikan tersebut, suatu bangsa meletakkan harapan besar untuk mempersiapkan masyarakat dan generasi mudanya agar dapat mewarisi nilai-nilai luhur bangsa dan mewujudkan kehidupan bangsa yang lebih baik dimasa yang akan datang Pendidikan yang baik dapat memberikan efek dalam proses penyadaran akan keberagamaan Indonesia melalui penguatan karakter generasi muda.

Undang-Undang Republik Indonesia Nomor 20 Tahun 2003 tentang Standar Nasional Pendidikan (SNP) merumuskan tujuan pendidikan Indonesia yaitu untuk mengembangkan potensi peserta didik agar menjadi manusia yang beriman dan bertakwa kepada Tuhan Yang Maha Esa, berakhlak mulia, sehat, berilmu, cakap, kreatif, mandiri dan menjadi warga negara yang demokratis serta bertanggung jawab.

Marzuki (2012, p.34), menjelaskan bahwa dalam menginternalisasikan pendidikan karakter melalui seluruh mata pelajaran yang ada, harus dengan komitmen dan sikap konsisten dari stakeholders dan seluruh praktisi pendidikan yang terlibat. Hal tersebut, harus menjadi dasar dalam upaya untuk mencapai keberhasilan dari pendidikan karakter. Zuchdi, Prasetya \& Masruri (2013, p.34), memaparkan bahwa keberhasilan dari pendidikan karakter dapat diawali melalui proses belajar mengajar di dalam kelas yang dilakukan oleh pendidik dengan melakukan pembelajaran terintegrasi.

Penerapan pendidikan karakter sangat mendesak untuk diinternalisasikan kepada peserta didik, dengan harapan kedepannya generasi muda Indonesia akan memiliki moralitas dan karakter yang kuat sebagai jati diri bangsa. SMKN 2 Mataram adalah salah satu lembaga pendidikan yang telah menjalankan pendidikan karakter. Sekolah menengah kejuruan ini, mengimplementasikan 
pendidikan karakter dalam proses pembelajaran dan seluruh kegiatan sekolah. SMKN 2 Mataram menjadi leading of character di Provinsi Nusa Tenggara Barat, sekolah ini medapatkan kepercayaan dalam menanamkan pendidikan karakter.

Berdasarkan penjelasan di atas, maka pendidikan karakter berbasis multikultural di SMKN 2 Mataram menawarkan satu alternatif melalui penerapan strategi dan konsep pendidikan berbasis pemanfaatan keragaman yang ada di lingkungan sekolah. Pendekatan multikultural merupakan strategi efektif dalam mendukung penerapan pendidikan karakter di sekolah yang memanfaatkan keberagaman latar belakang kebudayaan dari para peserta didik, sebagai salah satu kekuatan untuk membentuk sikap multikultural.

Karakter dapat dijadikan tolak ukur baik buruknya seseorang dalam bertindak. Karakter menjadi bagian penting yang melekat pada diri seseorang. Koesoema (2010, p.80), memahami bahwa karakter sama dengan kepribadian. Sebab kepribadian dianggap sebagai ciri, karakteristik, gaya, atau sifat khas dari diri seseorang yang bersumber dari bentukan-bentukan yang diterima melalui pengaruh lingkungan sekitar seperti keluarga, dan masyarakat. Lickona (2013, p.22), menjelaskan karakter sebagai "a reliable inner disposition to respon to situations in a morally good way". Karakter merupakan sifat alami seseorang dalam merespon situasi secara bermoral.

Marzuki (2012: 36) berpendapat bahwa karakter seringkali dihubungkan dengan istilah akhlak, etika, moral atau nilai. Hasil penelitian dari Raman \& Zamroni (2014, p.24), bahwauUntuk membentuk seorang siswa menjadi pribadi yang bertanggung jawab dan memiliki kedisiplinan, SMP Muhammadiyah 1 Tidore telah mengeluarkan kebijakan berupa sejumlah aturan baik yang sifatnya penalaran moral maupun penalaran konvensional. Aturan yang dikeluarkan bersifat penalaran moral karena terdapat tujuan-tujuan yang sifatnya membentuk berkarakter siswa

Agboola \& Tsai (2012, p.163-170), mengungkapkan bahwa "character is the realization of one's positive development as a person-intellectually, socially, emotionally, and ethically. To be a person of good character is to be the best person that one can be". Berdasarkan pernyataan ini, dapat dijelaskan bahwa karakter adalah realisasi dari perkembangan positif seseorang yang meliputi aspek intelektual, sosial, emosional, dan etis, sehingga dapat menjadi orang yang memiliki karakter baik dari kebanyakan orang lainnya. Berdasarkan berbagai pendapat di atas, dapat disimpulkan karakter merupakan cara individu berfikir, bersikap, dan bertindak sesuai dengan norma-norma, serta menjadi kebiasaan yang ditampilkan dalam kehidupan sehari-hari.

Pendidikan karakter adalah suatu sistem penanaman nilai-nilai karakter kepada seluruh warga masyarakat melalui pendidikan formal ataupun informal yang meliputi komponen pengetahuan, kesadaran, kemauan, dan tindakan untuk melaksanakan keseluruhan nilai-nilai tersebut (Wibowo, 2012, p.34). Pattaro (2016, p.11), menerangkan bahwa pendidikan karakter dianggap dapat memainkan peran penting dalam pembangunan identitas anak dan dapat menjadi sarana yang relevan untuk membangun pemuda melalui sosialisasi pendidikan karakter.

Lickona (2013, p.56), berpendapat bahwa pendidikan karakter mengandung tiga aspek karakter yang baik (component of good character), yakni: pengetahuan moral (moral knowing), perasaan moral (moral feeling), dan perbuatan moral (moral action).

Sanderse (2013, p.4), menjelaskan bahwa tujuan moral yang objektif dapat mendorong anak-anak untuk memiliki sifat seperti; kebajikan, keberanian, kesederhanan, keadilan, kejujuran, dan kasih sayang. Prestwich (2013, p.9), bahwa pendidikan karakter adalah suatu usaha yang disengaja untuk menumbuhkan dan menciptakan kebajikan.Untuk mewujudkan tujuan tersebut, peran keluarga, sekolah dan komunitas sangat menentukan pembangunan karakter anak-anak untuk kehidupan yang lebih baik di masa mendatang. Pendidikan karakter dilaksanakan melalui berbagai kegiatan dan program yang terus dikembangkan dalam rangka transformasi, dan pembudayaan nilai-nilai dasar moral. Nilai tersebut bersumber dari agama, pancasila, budaya, dan tujuan pendidikan nasional.

Schwartz (2012, p.3), menjelaskan bahwa nilai karakter dapat berasal dari kelompok budaya, kebiasaan masyarakat, dan bawaan individu, sehingga nilai karakter yang 
melekat pada diri seseorang dapat berubah dari waktu-waktu tergantung pada lingkungan sosial tempatnya berada, maka dari itu nilai karakter sangat mempengaruhi keyakinan, dan bertujuan memotivasi tindakan dari setiap individu.

Balitbang Puskur (2010, p.9-10) menyebutkan ada 18 nilai yang bersumber dari agama, Pancasila, budaya, dan tujuan pendidikan nasional yang diidentifikasi sebagai berikut; religius, jujur, toleransi, disiplin, kerja keras, kreatif, mandiri demokratis, rasa ingin tahu, semangat kebangsaan, cinta tanah air, menghargai prestasi, bersahabat, cinta damai, gemar membaca, peduli lingkungan, peduli sosial dan tanggungjawab. Ada enam pilar penting nilai karakter manusia yang dapat digunakan untuk mengukur dan menilai watak atau perilakunya (Fathurrohman \& Suryana, 2013, p.19), yaitu: respect (penghormatan), responsibility (tanggung jawab), citizenship civic duty (kesadaran berwarganegara), fairness (keadilan), carring (kepedulian), tustworthiness (kepercayaan). Menurut

Guru memiliki peranan yang sangat penting dalam menentukan keberhasilan pendidikan. Guru memegang peranan yang sangat strategis terutama dalam membentuk karakter serta mengembangkan potensi siswa. Muhaimin (2002, p.115), menjelaskan bahwa seorang guru wajib memiliki jiwa mulia sebagai kode etik profesi, diantaranya: 1) ikhlas dalam bekerja atau bekerja karena keridhoan Allah; 2) menjaga diri dan kehormatan; 3) menjadi teladan bagi anak didiknya; 4) menerapkan ilmunya dalam perbuatan dan tingkah laku sehari-hari; 5) sabar dalam mengajarkan ilmunya kepada anak didik; 6) tidak meremehkan mata pelajaran lainnya. Ada beberapa aspek penting dalam pendidikan karakter di lingkungan sekolah yang semestinya diperhatikan yaitu: pembenahan kurikulum, memperbaiki kompetensi, kinerja, dan karakter guru atau kepala sekolah, serta pengintegrasian dalam budaya sekolah (Syamsul Kurniawan, 2013: 108).

Mulyasa (2013, p.67), menjabarkan bahwa kepala sekolah merupakan pimpinan tertinggi yang sangat berpengaruh dan menentukan kemajuan sekolah. Secara sederhana kepemimpinan kepala sekolah dapat diartikan sebagai cara atau usaha kepala sekolah dalam mempengaruhi, mendorong, dan
Lickona (2013, p.74), komponen karakter baik dibagi menjadi tiga yaitu:

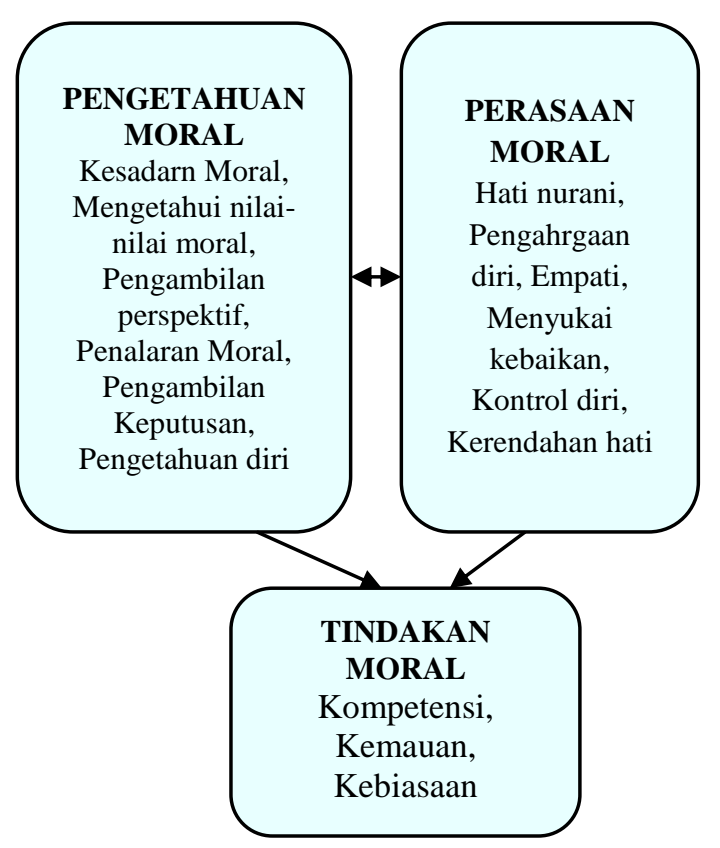

\section{Gambar 1. Komponen-Komponen Karakter Baik}

membimbing, mengarhakan guru, staf, peserta didik, orang tua peserta didik, dan seluruh pihak untuk mencapai tujuan pendidikan karakter. Kepala sekolah memiliki fungsi sebagai berikut: sebagai pendidik, sebagai manager sekolah, sebagai supervisior, sebagai leader, sebagai inovator, sebagai motivator (Kurniawan, 2013, p.122).

Strategi implementasi manajemen pendidikan karakter di sekolah dilakukan dengan mewujudkan komitmen guru dalam pelaksanaan pendidikan karakter (komponen guru), mengintegrasikan pendidikan karakter ke dalam kurikulum (komponen kurikulum), membuat rencana pembiayaan yang berpihak pada pelaksanaan pendidikan karakter (komponen pembiayaan), dan mendesain serta menciptakan budaya sekolah (komponen pengelolaan). Kesemua komponen tersebut akan bermuara pada tercapaiannya tujuan pendidikan karakter di sekolah.

$$
\text { Zamroni (2011, p.297), }
$$

mengemukakan bahwa budaya sekolah merupakan pola asumsi-asumsi dasar, nilainilai, keyakinan-keyakinan, dan kebiasaankebiasaan yang dipegang bersama oleh seluruh warga sekolah. Hanum (2013, p.59) menjelaskan bahwa kultur sekolah megacu pada seperangkat nilai, norma kepercayaan dan 
ritual yang menjadi pedoman bagi perilaku warga sekolah.

$$
\text { Hongboontri (2014, p.11), }
$$

menjelaskan bahwa pemahaman yang baik tentang budaya sekolah dapat menawarkan dasar untuk memperluas dan meningkatkan kualitas guru menuju keberhasilan serta kualitas sekolah. Ali, Sharma, \& Zaman (2016, p.59), menjelaskan bahwa tingginya tingkat budaya sekolah akan membantu mencapai tingginya efektivitas sekolah dalam mengembangkan budaya positif di sekolahsekolah. Multikurturalisme secara etimologis terbentuk dari tiga kata yaitu: Multi (banyak), Kultur (budaya), Isme (aliran/paham). Keragaman budaya itulah arti dari Nieto (2014, p.134), menjelaskan bahwa pendidikan multibudaya bertujuan untuk sebuah pendidikan yang bersifat anti rasis; memperhatikan keterampilanketerampilan dan pengetahuan dasar bagi warga dunia; penting bagi semua murid; menembus seluruh aspek sistem pendidikan; mengembangkan sikap, pengetahuan, dan keterampilan yang memungkinkan murid bekerja bagi keadilan sosial.

Ahmed (2016, p.139), menjelaskan bahwa "that multicultural competence requires the development of three levels of understanding: awareness, knowledge, and skills". Pernyataan di atas menunjukkan bahwa kompetensi multikultural membutuhkan pengembangan dari tiga tingkat pemahaman seperti: kesadaran, pengetahuan, dan keterampilan.

Banks (2005, p.3), menjelaskan bahwa multicultural education is at least three things: an idea or concept, an educational reform movement, and a process. Multicultural education incorporates the idea that alla students regardless of their gender and social class and their ethnic, racial, or cultural characteristics should have an equal opportunity to learn in school". Jadi, pendidikan multikultural tediri atas tiga hal yaitu, rencana atau konsep, gerakan yang berhubungan dengan perubahan pendidikan, dan proses pendidikan yang tujuan utamanya adalah untuk mengubah struktur lembaga pendidikan agar siswa baik perempuan maupun pria, siswa berkebutuhan khusus, dan siswa yang merupakan anggota dari kelompok ras, etnis, dan kultur yang bermacam-macam multikultural. Multikulturalisme adalah aliran atau paham tentang banyak budaya yang berarti mengarah pada keberagaman budaya (Hanum \& Raharja, 2007, p.5). Tilaar (2004: 83) menjelaskan bahwa multikultural mengarah pada adanya kebutuhan terhadap pengakuan (the need of recognition), dan legitimasi keragaman budaya atau pluralisme budaya. Zamroni (2013, p.58), menjabarkan bahwa kesadaran akan multikultural sebagai suatu realitas bermasyarakat perlu memegang teguh sifat tenggang rasa dan toleransi, sebab hal ini akan melahirkan suatu kesadaran baru bahwa kerja sama dengan segala perbedaan merupakan kebutuhan mutlak yang tidak dapat ditinggalkan

itu akan memiliki kesempatan yang sama untuk mencapai prestasi akademik di sekolah.

Banks (2008, p.32), mengidentifikasi ada lima dimensi pendidikan multikultural yang diperkirakan dapat membantu guru dalam mengimplementasikan beberapa program yang mampu merespon terhadap perbedaan. Dapat dilihat pada gambar berikut.

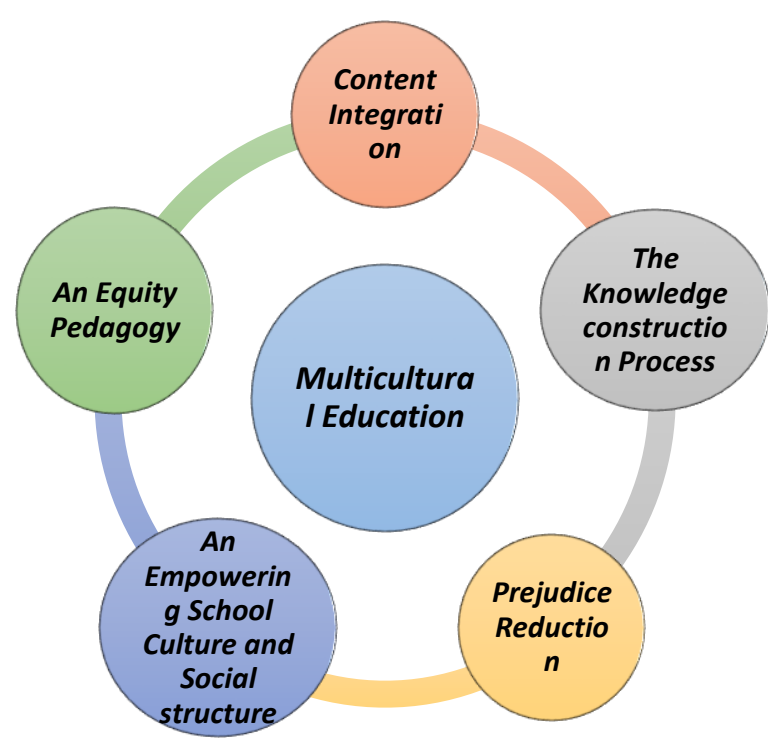

\section{Gambar 4. The Dimention of Multicultural Education (Banks, 2008, p. 32)}

Kelima dimensi pendidikan multikultural yang telah dikemukakan oleh banks di atas, merupakan cara untuk mengakomodir seluruh hak-hak peserta didik dalam memperoleh pendidikan yang sama, tanpa memandang pada hal-hal bawaan peserta didik. Dalam aktivitas pendidikan manapun, 
peserta didik merupakan sasaran (objek) dan sekaligus juga sebagai subjek pendidikan. Oleh karena itu, untuk memahami hakikat peserta didik yang beragam, para pendidik perlu menyadari dan memahami tentang ciri-ciri umum peserta didik. Dalam pendidikan multikultural, yang sangat penting bukanlah hasil melainkan proses yang dilakukan disatuan jenjang pendidikan memberikan akses dan kesempatan yang sama bagi semua semua peserta didik untuk mengembangkan potensi diri, untuk mencapai prestasi yang maksimal tanpa mempermasalahkan perbedaan latar belakang agama, suku, etnis, gender, kelas sosial, berkebutuhan khusus, ekonomi, dan budaya.

Pendidikan multikultural membantu setiap orang menjadi diri mereka sendiri dengan tetap menjunjung tinggi nilai-nilai perbedaan dalam bentuk sikap toleransi dan saling menghargai. Saliman, Mukminan, \& Wulandari (2014, p.16), menjelaskan bahwa pendidikan multikultural dapat dimaknai sebagai proses sosialisasi, enkulturasi, dan internalisasi tentang adanya keragaman budaya (multikultural) dalam masyarakat, sehingga siswa harus diajarkan dan ditanamkan tentang adanya perbedaan, serta perlunya masingmasing menghargai perbedaan yang ada. Model pendidikan multikultural yang dikembangkan dengan baik melalui seluruh manajemen yang konsisten, mampu menciptakan suasana sekolah yang sadar akan perbedaan. Praktik pendidikan multikultural lebih bermakna, jika seluruh elemen sekolah dapat saling menghargai dan hidup berdampingan sebagai satu kesatuan yang utuh dalam masyarakat yang multikutlural.

\section{Metode Penelitian}

Penelitian ini menggunakan metode kualitatif dengan pendekatan naturalistik. Penelitian kualitatif naturalistik digunakan untuk mengetahui, memahami dan mendeskripsikan implementasi pendidikan karakter di sekolah. Peneliti meyakini bahwa kualitatif naturalistik dapat membantu memahami masalah sosial lebih mendalam.

Penelitian ini dilakukan pada sekolah yang memiliki kriteria heterogen, baik suku, agama, sosial ekonomi, dan budaya. Penelitian dilaksanakan di SMK Negeri 2 Mataram, Pemilihan tempat penelitian berdasarkan pertimbangan-pertimbangan yang sejalan dengan tujuan penelitian. SMK Negeri 2 Mataram diputuskan dijadikan tempat penelitian, karena SMK Negeri 2 Mataram telah menerapkan pendidikan karakter dalam kehidupan di Sekolah,

Pemilihan subjek penelitian dilakukan dengan menggunakan teknik purposive sampling dan snowball sampling. Setting penelitian ini adalah semua pihak yang terlibat, dan seluruh kegiatan yang dilakukan dalam implementasi pendidikan karakter berbasis multikultural. Sumber data dalam penelitian ini digali melalui subjek penelitian yang sudah ditentukan dengan berbagai pertimbangan, yakni kepala sekolah, guru, dan siswa terkait proses implementasi pendidikan karakter berbasis multikultural.

Teknik pengumpulan data dalam penelitian ini dilakukan melalui tiga teknik, yaitu: wawancara, observasi, dan dokumentasi. Teknik wawancara dilakukan dengan dengan menggunakan pedoman wawancara yang berisi pertanyaan penelitian yang telah disusun sebelumnya, sesuai garis besar materi dan instrumen pertanyaan. Teknik observasi dilakukan dengan mencatat keseluruhan kegiatan dan peristiwa yang terjadi di lingkungan sekolah, terkait hal-hal yang berhubungan dengan proses implementasi pendidikan karakter berbasis multikultural. Kegiatan observasi yang dilaksanakan oleh peneliti di lapangan diabadikan dalam bentuk catatan lapangan (field note).

Teknik dokumentasi bertujuan untuk mempermudah peneliti dalam mengumpulkan data yang dibutuhkan untuk mendukung hasil, data dokumentasi dapat menjadi pendukung data primer yang diperoleh peneliti melalui observasi dan wawancara. Instrumen pengumpulan data dalam penelitian ini merupakan peneliti sendiri. Keabsahan data menggunakan teknik tringulasi (sumber dan teknik).

Analisis dalam penelitian ini menggunakan kualitatif deskriptif dengan tujuan agar dapat mendeskripsikan berbagai bentuk dan implementasi pendidikan karakterkter berbasis multikultural di SMK Negeri 2 Mataram. Analisis data menggunakan model interaktif dengan langkah: reduksi data, penyajian data, dan penarikan kesimpulan. Reduksi data dalam penelitian berlangsung 
secara terus menerus selama peneliti berada dalam setting penelitian.

Tahap ini dilakukan setelah peneliti melakukan pengumpulan (observasi dan wawancara). Penyajian data dilakukan oleh peneliti setelah melewati proses reduksi data, peneliti berusaha menabarkan secara rinci berdasarkan klasifikasi temuan lapangan. Kesimpulan dapat diambil apabila proses penyajian data yang dilakukan oleh peneliti telah tersusun dengan baik.

\section{Hasil Penelitian dan Pembahasan}

\section{Hasil Penelitian}

\section{Implementasi Pendidikan Karakter berbasis Multikultural di SMK Negeri 2 Mataram}

SMK Negeri 2 Mataram salah satu lembaga pendidikan formal yang telah menerapkan pendidikan karakter di kota Mataram. Keseluruhan nilai-nilai pendidikan karakter diimplementasikan dalam kebijakankebijakan sekolah, peraturan sekolah, proses dan kegiatan pembelajaran, serta kegiatankegiatan pendukung di luar pembelajaran formal. Sementara itu, program yang dilaksanakan merupakan cara yang dilakukan untuk mencapai visi, misi, dan tujuan sekolah. Program penerapan pendidikan karakter, yang dilakukan di SMK Negeri 2 Mataram adalah upaya sekolah dalam penanaman nilai karakter siswa.

Pendidikan karakter mempunyai urgensi yang sangat penting untuk dilaksanakan di sekolah. Hal ini dikarenakan semakin merosotnya akhlak anak-anak didik yang dipengaruhi oleh efek negatif globalisasi dan modernisasi, sehingga proses pembentukan karakter siswa di SMK Negeri 2 Mataram adalah cara yang paling tepat dilakukan pihak sekolah untuk mengurangi dan mencegah halhal negatif terhadap siswa.

Nilai-nilai karakter yang dikembangkan berasal dari visi dan misi sekolah, yang dirumuskan dalam bentuk kebijakan sekolah yang diimplementasikan ke dalam programprogram pendukung terlaksananya pendidikan karakter yang diharapkan sebagai berikut.

\section{Komitmen manajemen sekolah terhadap penanaman nilai-nilai karakter berbasis multikultural}

Komitmen dan dukungan manajemen sekolah sangat penting terhadap terlaksananya kebijakan, serta programprogram untuk mencapai keberhasilan penanaman pendidikan karakter siswa. Sekolah sebagai institusi pendidikan formal khususnya sekolah kejuruan, memiliki tugas menghasilkan lulusan yang berdaya saing dan memiliki karakter kuat.

Manajemen sekolah memiliki peran sentral untuk memberikan kontribusi terhadap pembentukan program-program jangka pendek, dan program jangka panjang agar dikemudian hari visi misi sekolah dapat tercapai. Manajemen sekolah mempunyai andil besar dalam mengatur dan menjalankan keseluruhan proses pembelajaran. Mulai dari mengembangkan kurikulum, pelaksanaan semua programprogram, menyediakan fasilitas pembelajaran, dan mengevaluasi keterlaksanaan program.

Dukungan manajemen sekolah tidak hanya sebatas melaksanakan dan mengevaluasi program yang dicanangkan. Melainkan juga meningkatkan kualitas para pendidik. Peningkatan kualitas ini dilakukan untuk memberikan motivasi kepada pendidik, agar pendidik memiliki karakter yang baik dan siap untuk menerapkan nilai-nilai karakter positif terhadap peserta didik. Pengelolaan manajemen sekolah yang telah dilakukan, akan memberikan ruang lebih besar agar sekolah berkembang sesuai dengan kondisi sosial budaya yang ada di sekitarnya. Peningkatan kualitas pendidik merupakan salah satu usaha sekolah untuk meningkatkan kualitas proses pembelajaran.

Program-program pembinaan dilakukan sebagai bentuk upaya sekolah, dalam mewujudkan misi sekolah untuk mengembangkan diri. Pencapaian dari misi sekolah ini agar SMK Negeri 2 Mataram dapat menjadi sumber penghasil pendidik berkualitas tinggi yang mampu menguasai ilmu pengetahuan dan memiliki karakter mulia. Dari misi tersebut jelas tergambar bahwa SMK Negeri 2 Mataram sebagai sebuah lembaga pendidikan formal tidak sekedar mempekerjakan guru untuk mendidik, tetapi lebih dari itu para guru pun 
harus memiliki pengetahuan yang luas dan berkarakter.

\section{Pengintegrasian pendidikan karakter melalui intrakurikuler}

Pendidikan karakter dilaksanakan melalui kegiatan belajar-mengajar. Proses pembelajaran dilaksanakan oleh guru di kelas, sesuai dengan mata pelajaran masing-masing. Penanaman nilai-nilai karakter yang dilakukan oleh para guru sesuai dengan amanat kurikulum 2013. Guru mata pelajaran melaksanakan pendidikan karakter melalui kegiatan belajar mengajar di kelas. Guru diarahkan untuk menanamkan daya kritis dan kreatifitas peserta didik, kemampuan bekerja sama, serta keterampilan mengambil keputusan. Penanaman pendidikan karakter, dan semua tahapan yang dilaksanakan oleh guru dalam proses pembelajaran tercantum dalam RPP. Guru mempersiapkan pengintegrasian pendidikan karakter dalam mata pelajaran, dimulai dari perencanaan, pelaksanaan, hingga pada proses penilaiannya secara sistematis dan terstruktur.

Guru sebagai pendidik profesional yang mempunyai tugas utama mendidik, membimbing, menilai, dan mengevaluasi. Pengintegrasian pendidikan karakter dalam proses pembelajaran tidak dapat berjalan lancar, tanpa adanya hubungan timbak balik antara guru dan siswa. Penanaman nilai karakter berhasil diintegrasikan dengan melihat realitas keberagaman pada diri siswa, yang memiliki kondisi berbeda secara potensi, sehingga guru membangun proses belajar-mengajar didasarkan pada kesadaran akan keberagaman. kondisi lingkungan sekolah dibangun dengan rasa saling percaya, sehingga menciptakan suasana belajar yang nyaman. Fakta ini dapat menjadi landasan dalam memahami keberagaman yang terdapat di lingkungan sekolah, salah satu hal yang dilakukan adalah memberikan perlakuan yang sama terhadap seluruh elemen sekolah, khususnya siswa. Perlakuan tersebut diinternalisasi ke dalam seluruh proses kegiatan di sekolah.

Keberhasilan guru menerapkan pendidikan karakter dalam kegiatan intrakurikuler tidak terlepas dari komitmen dan kerja sama semua warga sekolah dalam mewujudkan visi dan misi sekolah. Kegiatan intrakurikuler merupakan bagian penting dalam proses penanaman nilai-nilai karakter di sekolah. Program-program yang dilaksanakan adalah sikap nyata keseriusan pihak sekolah untuk membentuk karakter siswa. Segala bentuk program yang dilaksanakan sekolah, sedapat mungkin difasilitasi oleh pihak sekolah, agar sekolah dapat menunjukkan eksistensinya dalam melakukan penanaman nilai-nilai karakter terhadap seluruh warga sekolah. Pihak sekolah menfasilitasi seluruh kegiatan belajar mengajar, tanpa membatasi potensi siswa. Sekolah memberikan kebebasan kepada setiap siswa untuk mengembangkan diri sesuai dengan budayanya.

\section{Pembentukan karakter melalui kegiatan ekstrakurikuler}

Kegiatan

ekstrakurikuler

merupakan salah satu usaha sekolah dalam memberikan kesempatan kepada peserta didik untuk mengembangkan potensi minat dan bakat. Kegiatan ekstrakurikuler juga memiliki peran strategis dalam pembentukan karakter siswa. Melalui kegiatan ekstrakurikuler para siswa difasilitasi oleh sekolah untuk mengembangkan potensi yang mereka miliki. SMK Negeri 2 Mataram sampai dengan saat ini telah memiliki 11 jenis cabang ekstrakurikuler yaitu: sepak bola dan futsal, bola basket, bola voly, gendang beleq, tari tradisional, paskibraka, pramuka, bela diri, PKS, PMR, mading dan imtaq. Semua cabang ekstrakurikuler tersebut didirikan dengan maksud untuk mewadahi minat dan bakat siswa, agar minat dan bakat siswa dapat dikembangkan semaksimal mungkin, serta dapat mengarahkan siswa pada kegiatan-kegiatan yang positif. Setiap ekstrakurikuler memiliki pembina masing-masing yang betugas untuk melaksanakan dan menanamkan nilai-nilai karakter, dalam kegiatan-kegiatan ekstrakurikuler.

Pengembangan karakter siswa dalam kegiatan ekstrakurikuler ini dilakukan melalui training building character, membangun kerja sama dengan pihak lain untuk menanamkan dan mengembangkan nilai-nilai karakter pada 
siswa. Pihak sekolah juga mengadakan kerjasama dan komunikasi dengan orang tua siswa, dengan melibatkan orang tua siswa dalam berbagai kegiatan ekstrakurikuler. pembinaan pendidikan karakter melalui program ekstrakurikuler dapat dilakukan dalam bentuk kegiatan di luar proses pembelajaran inti, antara lain; imtaq, sholat berjamaah, pesantren kilat bagi yang beragama muslim, peringatan hari besar keagamaan bagi masing-masing agama, dan lain sebagainya. Tujuan akhir dari kegiatan ini adalah dapat mewujudkan visi dan misi sekolah, serta menghasilkan siswa-siswi yang berkarakter.

\section{Pengembangan karakter melalui jaringan kerja}

Proses pengembangan karakter siswa tidak hanya dilakukan pada tataran internal sekolah, tetapi juga ikut melibatkan berbagai pihak melalui jaringan kerja yang telah dibina sekolah. Sekolah memiliki koneksi dengan berbagai lembaga pemerintah maupun non pemerintah. Upaya tersebut dilakukan sebagai bentuk komitmen SMK Negeri 2 Mataram dalam penanaman pendidikan karakter. Pengembangan karakter melalui jaringan kerja merupakan salah satu strategi yang dijalankan SMK Negeri 2 Mataram dengan melibatkan unsur-unsur lembaga pemerintah maupun non pemerintah, seperti; bekerja sama dengan Polri dan TNI, BNN, Organisasi kepemudaan, BKKBN, dan beberapa lembaga lainnya.

Bentuk kerja sama tersebut adalah berupa seminar-seminar yang diadakan pihak sekolah dengan menghadirkan pembicara-pembicara dari berbagai lembaga pemerintah atau non pemerintah. Hal ini bertujuan untuk memberikan pemahaman terhadap siswa, membantu pengembangan karakter siswa, dan memberikan motivasi terhadap para siswa. Kerjasama yang digagas pihak sekolah ini agar para siswa memiliki suasana belajar yang baru, mendapatkan ilmu, serta pengalaman baru. Karena kegiatan-kegiatan yang diadakan tersebut berkaitan dengan isu-isu dan permasalahan yang sedang berkembang. Dengan adanya seminarseminar itu diharapkan para siswa dapat lebih kritis dan bertanggung jawab atas kehidupan sosialnya di sekolah maupun di luar sekolah.

\section{Penanaman karakter melalui tata tertib sekolah}

Pembentukan karakter siswa di SMK Negeri 2 Mataram diawali dengan penerapan tata tertib sekolah. Tata tertib sekolah merupakan salah satu strategi yang diterapkan sekolah untuk membiasakan para siswa-siswi disiplin. Seluruh warga sekolah harus mematuhi tata tertib ataupun aturan yang telah ditetapkan sekolah. Tata tertib tersebut dibagi menjadi dua bagian yaitu, tata tertib bagi siswa dan tata tertib bagi guru serta karyawan sekolah. Penanaman pendidikan karakter berjalan dengan baik terutama melalui penegakan tata tertib sekolah. Setiap siswa yang melanggar mendapatkan sanksi. Sanksi tersebut mulai dari sanksi ringan berupa teguran sampai skorsing.

Selain memberikan sanksi atau hukuman, sekolah juga memberikan reward kepada siswa-siswi yang selalu disiplin dan menaati tata tertib sekolah. Reward ini diberikan oleh pihak sekolah pada akhir semester, dengan tujuan agar siswa semakin termotivasi untuk disiplin dan taat terhadap tata tertib yang ada. Sanksi dan reward bukan hanya diberikan kepada siswa-siswi, tetapi juga berlaku untuk para guru dan karyawan di lingkungan SMK Negeri 2 Mataram. Dengan demikian, penanaman pendidikan karakter di SMK Negeri 2 Mataram dilaksanakan oleh seluruh warga sekolah tanpa terkecuali. Proses penanaman nilai-nilai karakter melalui tata tertib sekolah dilaksanakan secara demokratis.

\section{Pembinaan karakter melalui budaya sekolah}

Budaya sekolah merupakan tradisi atau ciri khas sekolah yang tumbuh dan berkembang sesuai dengan komitmen dan nilai-nilai yang dianut oleh seluruh warga sekolah. Tradisi tersebut mewarnai seluruh kualitas kehidupan sosial di lingkungan sekolah, yang terwujud ke dalam tata tertib, peraturan-peraturan, kebiasaan-kebiasaan, serta karakteristik lainnya dalam kehidupan antar warga sekolah. Karakteristik tersebut dapat dilihat pada kekhasan tata letak bangunan, ornamen-ornamen hiasan pada 
setiap sudut ruangan, kebersihan kelas, kondisi dan suasana proses belajarmengajar, gaya kepemimpinan kepala sekolah, merupakan bagian penting dari budaya sekolah.

Budaya sekolah tercermin pada visi misi sekolah, karena visi dan misi sekolah merupakan hal inti dari kebiasaankebiasaan yang dijalankan sekolah. Kebiasaan tersebut adalah perwujudan dari budaya sekolah. Kebiasaan-kebiasaan dapat terlihat pada kehidupan sosial di lingkungan sekolah, seperti; guru-guru yang bersalaman dan saling sapa setiap hari, sikap siswa-siswi di lingkungan sekolah yang bersahabat, sopan dan santun, disiplin menjalankan ibadah sesuai ajaran masingmasing, sholat berjamaah, budaya menabung, dan lain sebagainya.

Komitmen dan usaha SMK Negeri 2 Mataram mengembangkan budaya sekolah sangat baik untuk diapresiasi, hal itu terlihat dari 10 point budaya sekolah yang telah berusaha diwujudkan, atau biasa disingkat dengan $10 \mathrm{~K}$ sebagai berikut; a) keimanan, b) ketaqwaan, c) kedisiplinan, d) ketertiban, e) keamanan, f) kebersihan, g) keindahan, h) kerindangan, i) kenyamanan, j) kekeluargaan. Kesepuluh budaya sekolah tersebut adalah salah satu kebijakan ataupun peraturan sekolah yang mengikat seluruh warga sekolah. Budaya sekolah inilah yang menjadi ciri khas dari SMK Negeri 2 Mataram, serta menjadi pembeda dari sekolah-sekolah lain.

Budaya sekolah yang ada di SMK Negeri 2 Mataram sudah mendarah daging dan menjadi kebiasaan yang sulit untuk ditinggalkan, yaitu 3S (salam, senyum, sapa), dan budaya sederhana (menabung). Sekolah memiliki kegiatan rutin yang dilaksanakan setiap pagi, yaitu bersalaman. setiap pagi para guru memiliki tugas untuk menyambut siswa di depan gerbang sekolah. Guru berbaris untuk bersalaman dan memeriksa kelengkapan siswa-siswi mulai dari ujung kepala hingga ujung kaki. Hal-hal yang diperiksa adalah kerapian pakaian. Pemeriksaan tersebut dilakukan agar siswa tidak melanggar tata tertib sekolah.

$\begin{array}{lll} & \text { Nilai-nilai pendidikan karakter } \\ \text { yang dikembangkan SMK } & \text { Negeri 2 } \\ \text { Mataram. Implementasi } & \text { pendidikan }\end{array}$

karakter tidak terlepas dari nilai-nilai karakter yang dikembangkan di SMK Negeri 2 Mataram. Penanaman nilai-nilai karakter merupakan sebuah usaha untuk mendidik siswa, agar dapat memiliki karakter yang baik dan mampu mempraktikkanya dalam kehidupan seharihari, sehingga bisa memberikan kontribusi positif bagi lingkungan sosialnya. SMK Negeri 2 Mataram mengembangkan sembilan nilai karakter sebagai berikut: religius, disiplin, berprestasi, peduli lingkungan, mandiri, toleransi, kompetitif, saling menghargai, dan semangat kebangsaan. Nilai-nilai karakter ini yang berusaha untuk terus ditanamkan kepada seluruh warga sekolah, sehingga tujuan dari pembentukan karakter siswa dapat terwujud.

Siswa di SMK Negeri 2 Mataram diarahkan untuk memahami nilai-nilai karakter tersebut melaui prosedur empiris dengan harapan bahwa siswa dapat memahami, menilai, dan menerapkan perilaku mulia dalam kehidupan sehari-hari. Pemahaman siswa ini, harus didukung oleh pemahamannya terhadap keberagamaan yang terdapat di lingkungan sekolah melalui wujud sikap multikultural. Sikap multikultural dimunculkan oleh sekolah dalam kehidupan sosial yang terbangun di lingkungan sekolah.

Nilai-nilai pendidikan karakter diimplementasikan dalam berbagai kegiatan, baik yang berada di dalam lingkungan sekolah maupun di luar lingkungan sekolah, yang bertujuan membentuk karakter siswa dalam segala situasi. Siswa didorong untuk berprestasi, dan mampu bersaing sesuai tuntutan zaman. Semua warga sekolah diberikan kesempatan yang sama dalam mengembangkan potensi yang dimiliki tanpa memandang latar belakang agama, sosial, ekonomi, suku, budaya, dan bahasa, sehingga dikemudian hari dapat bermanfaat bagi masyarakat serta mampu menyesuaikan diri dalam keadaan atau kondisi apapun.

Faktor Pendukung dan Penghambat Penerapan Pendidikan Karakter berbasis Multikultural di SMK Negeri 2 Mataram 
Faktor pendukung pelaksanaan pendidikan karakter di SMK Negeri 2 Mataram, terdiri dari faktor internal dan faktor eksternal. Faktor internal sebagai berikut: 1) tata tertib sekolah yang diterapkan dengan ketat; 2) komitmen dan kerjasama yang baik antara kepala sekolah, guru, dan siswa; 3) keterlibatan orang tua wali murid dalam berbagai aspek kegiatan sekolah; 4) komitmen dan kepemimpinan kepala sekolah yang demoktaris; 5) peran aktif pendidik dalam penerapan pendidikan karakter pada proses pembelajaran. Tenaga pendidik juga memegang peranan penting. Pendidik yang ada di SMK Negeri 2 Mataram merupakan tenaga pendidik yang berkualitas dan memiliki jiwa profesionalitas tinggi terhadap bidangnya; 6) keterlaksanaan budaya sekolah yang menjadi kebiasaan bagi seluruh warga sekolah. Budaya sekolah positif yang tercipta di lingkungan sekolah, dapat menumbuhkan semangat dan motivasi terhadap proses belajar mengajar, sehingga mampu mencetak output yang berkualitas serta berkarakter mulia.

\section{Pembahasan}

Sekolah bertujuan untuk mendidik dan menghasilkan peserta didik yang memiliki karakter mulia, dan kuat. Dimana karakter ini merupakan kepribadian seseorang yang akan menentukan baik buruknya tindakannya dalam kehidupan bermasyarakat. Lembaga sekolah memiliki pengaruh terhadap pembentukan karakter atau akhlak peserta didik. Hal ini sejalan dengan yang diungkapkan Koesoema (2010, p.80), bahwa karakter sama dengan kepribadian, sebab kepribadian dianggap sebagai ciri atau karakter diri seseorang yang bersumber dari bentuk-bentuk yang diterima melalui pengaruh lingkungan sekitarnya.

Keberhasilan penanaman pendidikan karakter dapat terlihat dalam kehidupan seharihari siswa di lingkungan sekolah maupun di luar lingkungan sekolah. Sebagaimana yang dijelaskan Lickona (2013, p.22), bahwa karakter sebagai "a reliable inner disposition to respon to situations in a morally good way". Karakter merupakan sifat alami seseorang dalam merespon situasi secara bermoral. Sifat tersebut harus dimanifestasikan dalam tindakan melalui tingkah laku yang positif, baik, jujur, bertanggung jawab, menghormati orang lain,
Faktor yang menghambat implementasi pendidikan karakter berbasis multikultural di SMK Negeri 2 Mataram diantaranya; background siswa yang beragam, sehingga dibutuhkan kerja keras dan penuh kesabaran dalam memberikan pemahaman tentang pentingnya sikap multikultural; kebiasaaan dan budaya dari lingkungan tempat tinggal asal yang kurang mendukung, kurangnya kesamaan pemahaman antara warga sekolah terkait pentingnya kesadaran multibudaya, sehingga pihak sekolah diharapkan mampu memberikan pemahaman dan pandangan yang sama, kepada siswa dan seluruh warga sekolah terkait visi, misi, dan keberagaman yang ada di lingkungan sekitarnya, agar siswa memiliki dasar sikap multikultural yang kuat; lingkungan teman sebaya dan media elektronik dapat memberikan pengaruh pada perilaku siswa; evaluasi program-program pendidikan karakter yang belum optimal, sehingga mempengaruhi proses penanaman karakter.

serta semua nilai-nilai moral yang baik lainnya.

Implementasi pendidikan karakter di SMK Negeri 2 Mataram merupakan upaya penanaman nilia-nilai karakter dalam segala aspek, melalui kebijakan sekolah, program, dan kegiatan sekolah. Penanaman pendidikan karakter terintegrasi pada setiap kegiatan yang dilakukan oleh siswa, dalam kegiatan intrakurikuler maupun ekstrakurikuler. Untuk menjalankan kegiatan intrakurikuler dan ekstrakurikuler dibutuhkan bantuan guru sebagai role model pendidikan karakter, sehingga penanaman karakter pada siswa dapat lebih maksimal.

Guru dijadikan role model dalam penerapan nilai-nilai karakter, dengan tujuan agar guru dapat menjadi contoh bagi siswa, dimana setiap guru tidak hanya memiliki peran tunggal untuk transfer knowledge, tetapi juga memiliki peran ganda sebagai fasilitator, motivator, dan teladan bagi siswa. Guru merupakan faktor penting yang mempunyai pengaruh terhadap keberhasilan pendidikan karakter di sekolah. Hal ini sejalan dengan yang dijelaskan Mulyasa (2013, p.71), bahwa fungsi guru bersifat multifungsi, agar guru dapat mengembangkan pendidikan karakter 
secara efektif, serta dapat meningkatkan kualitas pendidikan, khususnya

Tahapan pendidikan karakter berbasis multikultural di SMK Negeri 2 Mataram meliputi; Pertama, tahapan sosialisasi; Kedua, pengembangan kurikulum pendidikan karakter; Ketiga, mencanangkan tujuan pendidikan multikultural; Keempat, pelaksanaan pendidikan karakter melalui kebijakan, program, dan kegiatan sekolah; Kelima, mengadakan evaluasi jangka pendek, jangka menengah, dan jangka panjang. Penerapan pendidikan karakter dijabarkan dalam bentuk program-program yang dijalankan oleh pihak sekolah. Sekolah merupakan tempat yang efektif sebagai wadah pembinaan, pengembangan, dan pembentukan karakter. Namun untuk mencapai tujuan itu dibutuhkan komitmen manajemen sekolah terhadap penerapan pendidikan karakter, sehingga pembentukan karakter perlu didasarkan pada situasi yang tepat, salah satunya adalah manajemen sekolah yang memiliki komitmen kuat dalam penerapan seluruh programprogram untuk mencapai keberhasilan pendidikan karakter.

Manajemen sekolah yang dikelola dengan baik dan terstruktur, akan berdampak terhadap optimalisasi penerapan pendidikan karakter secara menyeluruh. Manajemen sekolah juga memiliki peranan untuk mengatur dan menjalankan keseluruhan kegiatan pembelajaran. program pendidikan karakter yang dikembangkan di SMK Negeri 2 Mataram, bukan hanya tentang manajemen sekolah. Lebih dari itu, melalui programprogram dibagi ke dalam beberapa bagian yang mempengaruhi penerapan pendidikan karakter antara lain; Pengintegrasian pendidikan karakter melalui kegiatan intrakurikuler dan ekstrakurikuler. Pendidikan karakter dilaksanakan melalui kegiatan belajarmengajar. Proses pembelajaran dilaksanakan oleh guru di kelas, sesuai dengan mata pelajaran masing-masing.

Pelaksanaan integrasi pendidikan karakter yang berbasis multikultural dalam pembelajaran harus di dukung oleh keteladanan guru dalam bersikap demokratis. Sikap demokratis seorang guru akan terlihat pada proses pembelajaran di kelas dengan memberikan kesempatan yang sama kepada setiap siswa untuk mengembangkan potensi yang ada pada dirinya, tanpa dipengaruhi oleh latar belakang mereka.

Pelaksanaan pendidikan karakter berbasis multikultural di SMK Negeri 2 Mataram, guru telah mampu mengelola kelas dengan menggunakan pendekatan multikultural yang tidak bias gender dalam proses pembelajaran. Pengintegrasian nilainilai pendidikan karakter dalam kegiatan intrakurikuler tidak hanya pada proses pembelajaran di dalam kelas, melainkan terlihat pada beberapa kegiatan rutin lainnya seperti; a. kegiatan upacara bendera yang dilakukan seluruh warga sekolah setiap hari senin dan hari-hari besar lainnya; b. kegiatan Imtaq umum yang dilakukan setiap hari jumat minggu genap setiap bulan; c. kegiatan peduli lingkungan (jum'at bersih) yang dikerjakan setiap hari jumat, minggu ganjil setipa bulan; d. kegiatan PKL yang merupakan program lapangan, biasanya dijadwalkan setiap tahun ajaran baru di semester genap bagi kelas XI, kegiatan PKL diikuti oleh seluruh siswa dari tiap-tiap program keahlian.

Seluruh ekstrakurikuler ini mempunyai tujuan yang sama untuk membantu sekolah mewujudkan keberhasilan penanaman pendidikan karakter berbasis multikultural. kegiatan ekstrakurikuler wajib diikuti oleh setiap siswa. Pengembangan karakter siswa melalui kegiatan ekstrakurikuler dapat membentuk siswa memiliki jiwa kepemimpinan, jiwa kompetitif, membentuk disiplin siswa, membangun rasa saling percaya, dan kepedulian sosial. Hasil penelitian ini, sejalan dengan hasil temuan Wening (2012) yang menjelaskan bahwa pendidikan nilai dirasakan sangat penting, bagi siswa yang diperoleh melalui keluarga, sekolah, teman sebaya, dan media massa. Faktor lingkungan memberikan pengaruh terhadap pembentukan karakter siswa.

Penanaman nilai karakter terhadap siswa yang diusahakan sekolah, harus dapat mengakomodir seluruh perbedaan yang ada di lingkungan sekolah, seperti perbedaan budaya, suku, bahasa, kemampuan intelektual siswa, status sosial-ekonomi, agama, dan gender, sehingga pelaksanaan pendidikan karakter berbasis multikultural membantu setiap individu siswa untuk memiliki sikap solidaritas, toleransi dan mampu memahami persepsi orang lain. Upaya pihak sekolah untuk membangun kesadaran warga sekolah akan 
perbedaan-perbedaan tersebut, tercermin dari sikap demokratis yang dibangun sekolah pada berbagai kegiatan implementasi pendidikan karakter.

Sekolah dapat melihat perbedaan yang ada sebagai potensi dalam membangun kesadaran, agar seluruh warga sekolah hidup berdampingan dengan berbagai perbedaan tersebut sebagai salah satu keunikan yang membedakannya dengan sekolah lain. Dalam proses penyelenggaraan pendidikan karakter, pihak sekolah harus dapat memberikan perlakuan yang sama kepada seluruh warga pentingnya sikap multikultural, untuk merespon perbedaan-perbedaan yang dimiliki setiap individu. Nilai-nilai pendidikan karakter

\section{Simpulan dan Saran}

\section{Simpulan}

Berdasarkan data hasil penelitian dan analisis yang telah dilakukan terkait implementasi pendidikan karakter berbasis multikultural di SMK Negeri 2 Mataram dapat disimpulkan bahwa implementasi pendidikan karakter berbasis multikultural dilaksanakan melalui langkah-langkah sebagai berikut: a. Komitmen manajemen sekolah, melalui peran kepala sekolah dan guru; b. Pembentukan karakter siswa di sekolah dimulai dari penerapan tata tertib dan peraturan sekolah yang ketat berlandaskan kesetaraan; c. Pengintegrasian pendidikan karakter pada program intrakurikuler yang mengakomodir seluruh perbedaan siswa; d. Pengintegrasian pendidikan karakter pada program ekstrakurikuler; e. Pembinaan karakter melalui budaya sekolah; f. Pengembangan karakter melalui jaringan kerja.

Dalam proses penerapan pendidikan karakter berbasis multikultural, pihak sekolah telah mengembangkan sembilan nilai-nilai karakter, seperti: nilai religius, mandiri, peduli lingkungan, berprestasi, toleransi, demokratis, semangat kebangsaan, kompetitif dan cinta damai. Pengembangan nilai-nilai pendidikan karakter yang berbasis multikultural harus memiliki prinsip integratif, komitmen yang kuat, dan konsisten untuk bersama-sama membangun kesadaran multikultural dalam rangka mencapai keberhasilan pembentukan karakter siswa.

Penerapan nilai karakter terhadap seluruh siswa harus didasarkan pada sekolah. Perlakuan yang sama tersebut tercermin dalam semua kebijakan dan program-program pendidikan yang dijalankan, tanpa memihak sekelompok golongan atau sekelompok orang.

Seluruh warga sekolah, guru, siswa, apapun latarbelakangnya ditempatkan pada posisi yang setara. Bukan hanya itu, sekolah juga dituntut dapat memberikan rasa keadilan bagi siapapun. Maka dari itu, pihak sekolah memiliki kewajiban membangun pemahaman dan pandangan yang sama terhadap

yang dikembangkan di SMK Negeri 2 Mataram harus didasarkan pada keberagaman latarbelakang siswa.

keberagamaan latarbelakang (agama, budaya, status sosial-ekonomi, suku, bahasa, dan kemampuan intelektual) yang ada di lingkungna sekolah. Seluruh program dan kegiatan yang dijalankan oleh pihak sekolah harus dapat dilaksanakan secara adil, dan menjunjung tinggi kesetaraan bagi seluruh warga sekolah.

Dengan demikian, pihak sekolah dapat menciptakan kenyamanan dan ketenteraman di lingkungan sekolah, sehingga terciptalah hubungan yang harmonis antar warga sekolah. Hubungan harmonis tersebut dapat dilihat pada pola kehidupan sehari-hari warga sekolah yang saling menghargai, dan menghormati satu sama lain, akhirnya dapat membangun sikap toleransi yang tinggi antar siswa. Hal ini terlihat dalam proses pembelajaran, dan interaksi sosial yang dibangun sampai di luar sekolah.

Faktor pendukung dan penghambat keberhasilan pendidikan karakter berbasis multikultural antara lain: a. faktor pendukung yakni, komitmen dan kerjasama yang baik antara kepala sekolah, guru, siswa, dan keterlibatan orang tua wali dalam berbagai aspek kegiatan sekolah; dukungan pihak pemerintah dan swasta dalam jaringan kerja; $b$. faktor penghambat implementasi pendidikan karakter di SMK Negeri 2 Mataram diantaranya, yaitu: 1) kebiasaan dan budaya lingkungan asal siswa yang berbeda; 2) lingkungan masyarakat yang kurang mendukung pelaksanaan pendidikan karakter; 3) lingkungan teman sebaya dan media elektronik dapat memberikan pengaruh pada perilaku siswa; 4) sarana prasarana yang belum 
lengkap; 5) evaluasi program-program pendidikan karakter yang belum optimal, sehingga mempengaruhi proses penanaman karakter.

Saran

Saran yang dapat diberikan berdasarkan kesimpulan penelitian ini adalah sebagai berikut: a. Penerapan pendidikan karakter yang dilaksanakan oleh SMK Negeri 2 Mataram dapat menjadi teladan bagi sekolah lain; b. Pihak sekolah diharapkan ke depannya melibatkan partisipasi masyarakat secara aktif dalam pelaksanaan program pendidikan karakter berbasis multikultural; c. Pihak sekolah diharapkan mampu memberikan pemahaman dan pandangan yang sama, kepada siswa dan seluruh warga sekolah terkait visi, misi, dan keberagaman yang ada di lingkungan sekitarnya, agar siswa memiliki dasar sikap multikultural yang kuat; d. Pemerintah diharapkan secara bersama-sama dengan sekolah segera melengkapi sarana dan prasarana, untuk menunjang keterlaksanaan proses belajar-mengajar, serta penerapan pendidikan karakter berbasis multicultural; e. Sekolah diharapkan melakukan proses evaluasi bertahap terhadap program-program pendidikan karakter yang lebih terarah, agar dapat menjadi instrumen perbaikan penerapan pendidikan karakter berbasis multikultural dikemudian hari. ; f. Komitmen, komunikasi, dan kerjasama antara guru, karyawan perlu ditingkatkan lagi, kaitannya dengan proses implementasi nilai pendidikan karakter dengan menekankan pemahaman sikap multikultural.

\section{Daftar Pustaka}

Agboola, A., \& Tsai, K. C. (2012). Bring character education into classroom. European Journal of Educational Research, 1, 2, 36-37.

Ahmed, H. (2016). Multicultural education: teachers perception and preparation. Journal of Ecucation and Practice, 7, $11,139$.

Ali, N., Sharma, S., \& Zaman, A. (2016). School culture and school effectiveness: Secondary schools in pakistan. Malaysian Online Journal of Educational Management, 4, 4, 50-56.
Badan Litbang Puskur. (2010). Badan pelatihan penguatan metodologi pembelajaran berdasarkan nilai-nilai budaya untuk membentuk daya saing karakter bangsa. Bandung: P4TK.

Badan Pusat Statistik. (2015). Statistik Indonesia: statistical yearbook of Indonesia. Jakarta: Badan Pusat Statistik. Diakses tanggal 18 September 2016 http://www.bps.go.id

Banks, J. (2008). An introduction to multicultural education. United States: Pearson.

Banks, J.A., \& Banks, M.C. (2005). Multicultural education; Issues and perspectives $5^{\text {nd }} e d$. New York: John Wiley and Sons.

Fathurrohman, Pupuh., Suryana, A.A., \& Fatrany, Fenny. (2013). Pengembangan pendidikan karakter. Bandung: Refika Aditama.

Hanum, Farida. \& Raharja, Setya. (2007). Pengembangan model pembelajaran pendidikan multikultural menggunakan modul sebagai suplemen pelajaran IPS di Sekolah Dasar. Diakses tanggal 06 Januari 2017 http://staff.uny.ac.id/dosen/prof-drfarida-hanum-msi

Hanum, Farida. (2013). Sosiologi pendidikan. Yogyakarta: Kanwa Publisher.

Hongboontri, C. (2014). School culture: teacher's beliefs, behaviors, and instructional practices.Australian Journal of Teacher Education, 39, 5, 6588.

Koesoema, D.A. (2010). Pendidikan karakter: program mendidik anak dizaman global. Jakarta: Grasindo.

Kurniawan, Syamsul. (2013). Pendidikan karakter, konsepsi dan implementasi secara terpadu di lingkungan sekolah, keluarga, perguruan tinggi, dan masyarakat. Yogyakarta: Ar-Ruzz. 
Lickona, Thomas. (2013). Pendidikan karakter, panduan lengkap mendidik siswa menjadi pintar dan baik (terjemahan Lita S). New York: Bantam book (buku asli terbit tahun 1991).

Marzuki. (2012). Pengintegrasian pendidikan karakter dalam pembelajaran di sekolah. Jurnal Pendidikan Karakter, 2, 1,36 .

Marzuki. (2013). Pendidikan karakter dalam keluarga perspektif islam. Yogyakarta: Fise UNY. Diakses tanggal 05 Oktober 2015.

Muhaimin. (2002). Paradigma pendidikan islam, upaya mengefektifkan pendidikan agama islam di sekolah. Bandung: PT. Remaja Rosdakarya.

Mulyasa. (2013). Manajemen pendidikan karakter. Jakarta: Bumi Aksara.

Nieto, S. (2014). Affirming diversity: the sociopolitical context of multicultural education. Journal Teaching Education, 7, 2, 133-134. http://www.tandfonline.com/doi/abs/10. $\underline{1080 / 10476219500 \mathrm{~s} 70219}$

Pattaro, C. (2016). Character education: themes and researches, an academic literature review. Italian Journal of Sociology of Education, 8, 1, 6-30.

Rama, Laa,. \& Zamroni. (2014). Pendidikan karakter siswa I SMP Muhammadiyah I Yogyakarta dan SMP Muhammadiyah 1 Kota Tidore. Jurnal Harmoni Sosial, 1,1, 12-26.

Republik Indonesia. (2003). Undang-Undang Republik Indonesia Nomor 20, Tahun 2003, tentang Sistem Pendidikan Nasional.

Saliman, Mukminan, \& Wulandari, Taat. (2014). Model pendidikan multikultural di sekolah pembauran Medan. Jurnal Cakrawala Pendidikan, 3, 392-401.
Sanderse, W. (2013). The meaning of role modelling in and character education. Journal of Moral Education, 42, 1, 2842.

Schwartz, S. H. (2012). An over view of the theory of basic values. Journal International Association for Cross Cultural Pscychology, 2, 1, 3-20.

Sleeter, C.E. (2014). Multiculturalsm and education for citizenship in a context of neoliberalism. New York: Routledge. Diakses tanggal 20 November 2015. https://www.academia.edu/6856381/Sle eter_Multicultural_education_and_citize nship.

Tilaar, H. A. R. (2004). Multikulturalisme: tantangan-tantangan global masa depan dalam transformasi pendidikan nasional. Jakarta: Grasindo.

Wening, Sri. (2012). Pembentukan karakter remaja awal melalui pendidikan nilai yang terkandung dalam pendidikan konsumen, kajian evaluasi reflektif kurikulum SMP di Yogyakarta.. Jurnal penelitian dan Evaluasi Pendidikan, 10, 151-167.

Wibowo, Agus. (2012). Pendidikan karakter: program membangun bangsa berparadigma. Yogyakarta: Pustaka Pelajar.

Zamroni. (2011). Dinamika peningkatan mutu. Yogyakarta: Gavin Kalam Utama.

Zamroni. (2013). Pendidikan demokrasi pada masyarakat multikultural. Yogyakarta: Gavin KalamUtama.

Zuchdi, Darmiyati., Zuhdan, K.P., \& Masruri, M.S. (2013). Model pendidikan karakter; terintegrasi dalam pembelajaran dan pengembangan kultur sekolah. Yogyakarta: Multi Presindo. 